\title{
Erratum to: Lubrication of dry sliding metallic contacts by chemically prepared functionalized graphitic nanoparticles
}

\author{
Suprakash SAMANTA ${ }^{1,2}$, Santosh Kumar SINGH ${ }^{1}$, Rashmi R. SAHOO ${ }^{1,2, *}$ \\ ${ }^{l}$ Enviromental Engineering Group, CSIR-Central Mechanical Engineering Research Institute, Durgapur 713209, India \\ ${ }^{2}$ Academy of Scientific and Innovative Research (AcSIR), Ghaziabad 201002, India \\ Received: 14 August 2018 / Revised: 24 November 2018 / Accepted: 15 April 2019 \\ (C) The author(s) 2019.
}

\section{Erratum to}

Friction 8(4): 708-725 (2020)

DOI 10.1007/s40544-019-0295-1

The original version of this article unfortunately contained incorrect author's name and address. On the first page of this article, instead of

Suprakash SAMANTA ${ }^{1,2}$, Santosh SINGH ${ }^{1}$, Rashmi R. SAHOO $^{1,2, *}$

${ }^{1}$ Surface Engineering \& Tribology Division, CSIR-Central Mechanical Engineering Research Institute, Durgapur 713209, India

${ }^{2}$ Academy of Scientific and Innovative Research (AcSIR), Ghaziabad 201002, India

It should read

Suprakash SAMANTA ${ }^{1,2}$, Santosh Kumar SINGH ${ }^{1}$, Rashmi R. SAHOO ${ }^{1,2, *}$

${ }^{I}$ Enviromental Engineering Group, CSIR-Central Mechanical Engineering Research Institute, Durgapur 713209, India

${ }^{2}$ Academy of Scientific and Innovative Research (AcSIR), Ghaziabad 201002, India
Open Access: This article is licensed under a Creative Commons Attribution 4.0 International License, which permits use, sharing, adaptation, distribution and reproduction in any medium or format, as long as you give appropriate credit to the original author(s) and the source, provide a link to the Creative Commons licence, and indicate if changes were made.

The images or other third party material in this article are included in the article's Creative Commons licence, unless indicated otherwise in a credit line to the material. If material is not included in the article's Creative Commons licence and your intended use is not permitted by statutory regulation or exceeds the permitted use, you will need to obtain permission directly from the copyright holder.

To view a copy of this licence, visit http://creativecommons.org/licenses/by/4.0/.

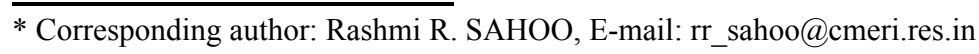

